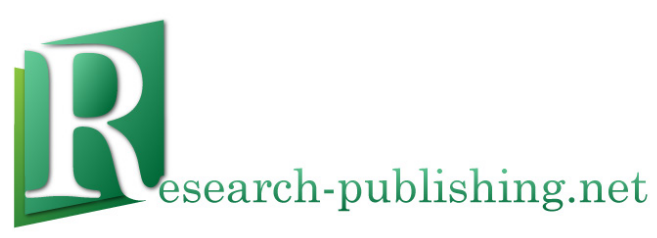

Published by Research-publishing.net, not-for-profit association Dublin, Ireland; Voillans, France, info@research-publishing.net

(C) 2014 by Research-publishing.net

Each author retains their own copyright

CALL Design: Principles and Practice

Proceedings of the 2014 EUROCALL Conference, Groningen, The Netherlands

Edited by Sake Jager, Linda Bradley, Estelle J. Meima, and Sylvie Thouësny

Rights: All articles in this collection are published under the Attribution-NonCommercial -NoDerivatives 4.0 International (CC BY-NC-ND 4.0) licence. Under this licence, the contents are freely available online (as PDF files) for anybody to read, download, copy, and redistribute provided that the author(s), editorial team, and publisher are properly cited. Commercial use and derivative works are, however, not permitted.

\title{
(@) $\mathbb{Q} \Theta$
}

Disclaimer: Research-publishing.net does not take any responsibility for the content of the pages written by the authors of this book. The authors have recognised that the work described was not published before, or that it is not under consideration for publication elsewhere. While the information in this book are believed to be true and accurate on the date of its going to press, neither the editorial team, nor the publisher can accept any legal responsibility for any errors or omissions that may be made. The publisher makes no warranty, expressed or implied, with respect to the material contained herein. While Research-publishing.net is committed to publishing works of integrity, the words are the authors' alone.

Trademark notice: product or corporate names may be trademarks or registered trademarks, and are used only for identification and explanation without intent to infringe.

Copyrighted material: every effort has been made by the editorial team to trace copyright holders and to obtain their permission for the use of copyrighted material in this book. In the event of errors or omissions, please notify the publisher of any corrections that will need to be incorporated in future editions of this book.

Typeset by Research-publishing.net

Cover design: (C) Raphaël Savina (raphael@savina.net)

Fonts used are licensed under a SIL Open Font License

ISBN13: 978-1-908416-19-3 (Paperback - Print on demand, black and white)

Print on demand technology is a high-quality, innovative and ecological printing method; with which the book is never 'out of stock' or 'out of print'.

ISBN13: 978-1-908416-20-9 (Ebook, PDF, colour)

ISBN13: 978-1-908416-21-6(Ebook, EPUB, colour)

Legal deposit, Ireland: The National Library of Ireland, The Library of Trinity College, The Library of the University of Limerick, The Library of Dublin City University, The Library of NUI Cork, The Library of NUI Maynooth, The Library of University College Dublin, The Library of NUI Galway.

Legal deposit, United Kingdom: The British Library.

British Library Cataloguing-in-Publication Data.

A cataloguing record for this book is available from the British Library.

Legal deposit, France: Bibliothèque Nationale de France - Dépôt légal: décembre 2014. 


\title{
Integrating CALL in ESOL classrooms: Understanding teachers' perspectives and meeting students' needs
}

\author{
Sara Farshad Nia ${ }^{1}$ and Ronnie Davey ${ }^{2}$
}

\begin{abstract}
In line with the needs of the 21 st century learners and dramatic improvements in schools' technological infrastructures, it is expected that the integration of digital tools into language learning courses would take a quicker pace and a smoother path. However, current research indicates that although this might be the case for foreign language learning courses, the situation differs for English Speakers of Other Languages (ESOL) classes in New Zealand schools. Despite the availability of various technologies, there is not much tendency for the integration of Computer Assisted Language Learning (CALL) tools into ESOL classrooms. Hence, this ongoing study explores the factors that contribute to the foregoing situation from ESOL teachers' perspectives in a New Zealand context. A series of indepth interviews were conducted with a group of secondary school ESOL teachers. The initial thematic analysis of the data suggested that any meaningful integration of IT into ESOL environments requires active involvement of teachers, students, and policy makers. Such factors as teachers' professional identity, teacher education and professional development programs, school and ministry policies, and students' demography and their needs impacted ESOL teachers' choice in IT adoption. The findings of this study have significant implications for teachers, teacher educators, and policy makers alike as a more specialized focus on such challenging situations should be taken into consideration when educating ESOL teachers on the integration of CALL.
\end{abstract}

Keywords: ESOL, CALL, professional development, TPACK, policy making.

1. University of Canterbury; sara.farshadnia@pg.canterbury.ac.nz.

2. University of Canterbury; ronnie.davey@canterbury.ac.nz.

How to cite this article: Farshad Nia, S., \& Davey, R. (2014). Integrating CALL in ESOL classrooms: Understanding teachers' perspectives and meeting students' needs. In S. Jager, L. Bradley, E. J. Meima, \& S. Thouësny (Eds), CALL Design: Principles and Practice; Proceedings of the 2014 EUROCALL Conference, Groningen, The Netherlands (pp. 72-76). Dublin: Research-publishing.net. doi:10.14705/rpnet.2014.000197 


\section{Introduction}

A plethora of literature exists on the factors contributing to teachers' uptake of information and communications technology (ICT) into their classrooms. Nevertheless, much of the related literature has tended to focus predominantly on teachers in general but factors impacting the IT adoption of ESOL/ESL teachers have remained understudied, especially in a New Zealand context (Ker, Adams, \& Skyrme, 2013). This is significant mainly because the nature of the subject, students' demography, teachers' concerns and students' needs in such courses differ from any other course in the school.

In New Zealand, as in many other countries, ESOL is considered more of a support rather than a language learning course, and therefore, is relatively isolated compared to other disciplines. The system operates in a way that for greater language support, students are withdrawn from the mainstream courses into a smaller group from 3 to 12 hours a week, depending on their language needs. The student population in ESOL classes also varies from that of other classes, usually consisting of refugee, migrant, international fee-paying, and short-term visiting students. Aside from different language levels of students, each group has different needs and seeks a distinctive goal when attending ESOL. Therefore, given the foregoing context, this study aims at investigating the factors that contribute to ESOL teachers' ICT adoption and integration in New Zealand and how they reinforce and influence each other.

\section{Method}

This ongoing study falls within the domain of inductive research and utilizes a phenomenological approach so as to come to a holistic understanding of ESOL teachers' IT technology integration experiences in their schools. A mixed-method data collection approach was employed by conducting semi-structured interviews with 25 secondary ESOL teachers in New Zealand. The interviews were also followed by attending teacher cluster meetings, observing classes, and analyzing related documents such as online teacher forums and schools' ESOL policies.

\section{Discussion}

The objective of this research is to identify the factors which ESOL teachers perceive as important in their ICT integration. Among the six main themes emerging from the data, teacher awareness, teacher professional identity, and teacher supportive environment will be addressed in this paper. 


\subsection{Teacher awareness}

Teachers' TPACK knowledge (Koehler \& Mishra, 2009) or their awareness of the affordances and constraints of different digital tools in their subject area, such as language learning, was found to be of great significance to the participants. Relevant professional development courses, teachers' connections with colleagues and friends, and teachers' auto-didacticism are the three main interconnected elements that teachers highlighted as the main factors contributing to teacher awareness. The following quotations indicate teachers' confusion regarding both the selection and utilization of programs in their own context while highlighting the role of collegial connections:

“Teachers don't know what to use. They don't know how it can be used. There is so much out there. You have to know what you want and what is gonna work in your classroom situation and that is the matter of just connecting with others" (Judy).

Similarly, the following teacher has emphasized her own enthusiasm and perseverance along with her connections as a factor in her technology uptake.

"I do it in my own time because I am interested in it. I am a tweeter user big time and I am connected quite well with IT community, like outside of schools, and students at the university computer sciences. So, they are always coming up with "Hey! You should look at this", or, "Gosh! This is a new app", or "I am doing this", and so, if it catches my imagination, I look at it and think how I can use that" (Fay).

\subsection{Teacher professional identity}

Professional identity has been conceptualized in various ways through different sub-identities in the literature. Teachers' beliefs and their perceptions of their subject matter (Connelly \& Clandinin, 1999), their relationship with students, their collegial interactions (Beijaard, Verloop, \& Vermunt, 2000; Silva \& Herdeiro, 2014), how teachers are being perceived by themselves and others (Ifanti \& Fotopoulou, 2010), and the roles teachers feel they have to play (Ezer, Gilat, $\&$ Sagee, 2010) are some of the main features that shape teachers' professional identity and impact their practice.

Four main sub-themes emerged as significant in ESOL teachers' professional identity development and IT integration, namely, relative importance of the content 
topic, teacher role perceptions, beliefs about students, and beliefs about teaching and learning.

The following are respective examples of the above sub-themes, which further clarify the categorization:

“Because I am not a course, I don't feel terribly valid and not really motivated" (Emily).

"Lot of students, they just wanna pass, get their credits, get out the other side. So how am I gonna help them achieve that? Maybe it's not focusing on so much ESOL technology" (Elizabeth).

"In myself, I didn't want the technology be an excuse for me to give up teaching. I said no, I want to connect with my students' world. It's the world they are in, Facebook and Twitter" (Jo).

\subsection{Teacher supportive environment}

Human technical and affective support and schools' supportive policies are the two main elements generating a supportive milieu. The immediate availability of a technician, colleague, family member, or techno-savvy student creates a supportive human atmosphere through which teachers can eliminate their fear of technology and enhance their IT integration experience. This is evident in the following statement by one of the teachers interviewed:

"We are very lucky here. We have got an IT department and a help desk or often one or the other of us [teachers] is in the classroom next door and we usually run across or grab somebody and they can help us. We also have IT angels, a student who is quite good at IT, to help out" (Becky).

Schools' supportive policies include ministry and school ESOL policies with regards to ESOL position in the school, ESOL financial and technological support, assessment policies, material development policies, and ESOL teacher recruitment policies. The following are some of the examples corresponding to these factors:

"Everyone is working in a group; they learn off each other, feed each other, to help this work for their department. The languages are doing the same. I have to do everything, I get frustrated and there is no one else there doing it with me" (Rebecca). 
"ESOL is like the broom cupboard, because ESOL is usually seen as just an add-on, or something you can do without. ESOL is marginalized, we can push from below, but it needs to come from the top" (Nikki).

"The ESOL teachers are really struggling to find those resources that they really need to help them. People are not getting as much help as there could be from the system" (Sarah).

\section{Conclusions}

The aim of this study was to understand ESOL teachers' perceptions of the factors that contribute to their technology integration. The findings signify a need for recognition of ESOL teachers' role and position in schools, and the need for the implementation of supportive policies from the ministry and schools. These may include providing subject-related ESOL professional development opportunities, generating relevant material and resources, and more IT-compatible assessment procedures. The results indicate that although teachers value the integration of CALL into their syllabi, it is not among their top priorities, largely due to various problems they face, that are unique to their environment.

\section{References}

Beijaard, D., Verloop, N., \& Vermunt, J. D. (2000). Teachers' perceptions of professional identity: An exploratory study from a personal knowledge perspective. Teaching and Teacher Education, 16(7), 749-764. doi:10.1016/S0742-051X(00)00023-8

Connelly, F. M., \& Clandinin, D. J. (1999). Shaping a professional identity: Stories of educational practice. New York: Teachers College Press.

Ezer, H., Gilat, I., \& Sagee, R. (2010). Perception of teacher education and professional identity among novice teachers. European Journal of Teacher Education, 33(4), 391-404. doi:10.10 80/02619768.2010.504949

Ifanti, A. A., \& Fotopoulou, V. S. (2010). Undergraduate students' and teachers' perceptions of professional development and identity formation: A case study in Greece. KEDI Journal of Educational Policy, 7(1), 157-174.

Ker, A., Adams, R., \& Skyrme, G. (2013). Research in applied linguistics and language teaching and learning in New Zealand (2006-2010). Language Teaching, 46(2), 225-255. doi:10.1017/ S0261444812000535

Koehler, M. J., \& Mishra, P. (2009). What is technological pedagogical content knowledge? Contemporary Issues in Technology and Teacher Education, 9(1), 60-70.

Silva, A. M., \& Herdeiro, R. (2014). The work, perceptions and professional development of teachers. Teaching Education, 25(2), 184-201. doi:10.1080/10476210.2012.759554 